The Canadian Mineralogist

Vol. 42, pp. 1013-1025 (2004)

\title{
CHEVKINITE-(Ce): CRYSTAL STRUCTURE AND THE EFFECT OF MODERATE RADIATION-INDUCED DAMAGE ON SITE-OCCUPANCY REFINEMENT
}

\author{
ELENA SOKOLOVA ${ }^{\S}$ AND FRANK C. HAWTHORNE \\ Department of Geological Sciences, University of Manitoba, Winnipeg, Manitoba R3T 2N2, Canada \\ GianCARLo DELLA VENTURA \\ Dipartimento di Scienze Geologiche, Università di Roma Tre, Largo S. Leonardo Murialdo 1, I-00146 Roma, Italy \\ PAVEl M. KARTASHOV \\ Institute of Geology of Ore Deposits, Mineralogy, Petrology and Geochemistry, \\ Russian Academy of Sciences, RU-109017 Moscow, Russia
}

\begin{abstract}
The crystal structure of annealed chevkinite-(Ce), ideally (REE,Ca) ${ }_{4} \mathrm{Fe}^{2+}\left(\mathrm{Ti}_{1}, \mathrm{Fe}^{3+}, \mathrm{Nb}_{4} \mathrm{Si}_{4} \mathrm{O}_{22}\right.$, monoclinic, C2/m, crystal $\left(2^{a n}\right) a 13.400(1), b$ 5.7232(4), $c$ 11.0573(9) $\AA, \beta 100.537(2)^{\circ}, V$ 833.7(2) $\AA^{3}$ and crystal $\left(3^{a n}\right) a 13.368(2), b 5.7243(6), c$ 11.041(1) $\AA, \beta$ 100.516(1),$V$ 830.7(2) $\AA^{3} ; Z=2$, from Mongolia, has been solved by direct methods and refined to $R_{1}$ values of

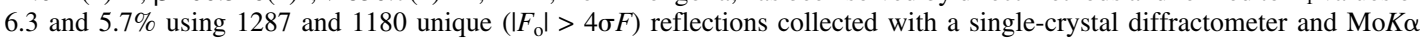
radiation. Electron-microprobe analysis gave: $\operatorname{crystal}\left(2^{a n}\right) \mathrm{SiO}_{2} 18.81, \mathrm{TiO}_{2} 15.66, \mathrm{FeO} 11.33, \mathrm{MnO} 0.24, \mathrm{CaO} 1.61, \mathrm{Nb}_{2} \mathrm{O}_{5} 1.55$, $\mathrm{ThO}_{2} 0.40, \mathrm{Y}_{2} \mathrm{O}_{3} 0.30, \mathrm{Ce}_{2} \mathrm{O}_{3} 23.45, \mathrm{La}_{2} \mathrm{O}_{3}$ 13.92, $\mathrm{Nd}_{2} \mathrm{O}_{3}$ 6.88, $\mathrm{Pr}_{2} \mathrm{O}_{3}$ 1.95, $\mathrm{Sm}_{2} \mathrm{O}_{3}$ 0.51, $\mathrm{Gd}_{2} \mathrm{O}_{3} 0.42, \mathrm{HfO}_{2} 0.01, \mathrm{ZrO}_{2} 0.28$, sum 97.32 wt.\%, and crystal $\left(3^{a n}\right) \mathrm{SiO}_{2} 18.53, \mathrm{TiO}_{2}$ 16.11, FeO 12.62, $\mathrm{MnO} 0.31, \mathrm{BaO} 0.02, \mathrm{CaO} 1.21, \mathrm{Nb}_{2} \mathrm{O}_{5} 1.69, \mathrm{ThO}_{2} 0.10, \mathrm{Y}_{2} \mathrm{O}_{3}$ 0.30, $\mathrm{Ce}_{2} \mathrm{O}_{3}$ 24.30, $\mathrm{La}_{2} \mathrm{O}_{3}$ 12.94, $\mathrm{Nd}_{2} \mathrm{O}_{3}$ 8.13, $\mathrm{Pr}_{2} \mathrm{O}_{3}$ 2.44, $\mathrm{Sm}_{2} \mathrm{O}_{3}$ 0.82, $\mathrm{Gd}_{2} \mathrm{O}_{3}$ 0.36, $\mathrm{HfO}_{2}$ 0.16, $\mathrm{ZrO}_{2}$ 0.08, $\mathrm{Ta}_{2} \mathrm{O}_{5}$ 0.03, $\mathrm{WO}_{3} 0.02$, sum 100.17 wt.\%. The corresponding chemical formulae are: $\left(2^{a n}\right):\left(C_{1.85} L_{1.11} N_{0.53} P_{0.15} S_{0.04} \operatorname{Gd}_{0.03} C_{0.32} \operatorname{Th}_{0.02}\right)_{\Sigma 4.05}$ $\left(\mathrm{Fe}^{2+}{ }_{0.85} \mathrm{Mn}^{2+}{ }_{0.04} \mathrm{Zr}_{0.03} \mathrm{Y}_{0.03} \mathrm{Ca}_{0.05}\right)_{\Sigma 1.00}\left(\mathrm{Ti}_{2.54} \mathrm{Fe}^{3+}{ }_{1.19} \mathrm{Nb}_{0.15}\right)_{\Sigma 3.88} \mathrm{Si}_{4.06} \mathrm{O}_{22}$ and $\left(3^{a n}\right):\left(\mathrm{Ce}_{1.88} \mathrm{La}_{1.01} \mathrm{Nd}_{0.61} \operatorname{Pr}_{0.19} \mathrm{Sm}_{0.06} \mathrm{Gd}_{0.03}\right.$ $\left.\mathrm{Ca}_{0.27} \mathrm{Y}_{0.03} \mathrm{Th}_{0.01}\right)_{\Sigma 4.08}\left(\mathrm{Fe}^{2+}{ }_{0.93} \mathrm{Mn}_{0.06} \mathrm{Zr}_{0.01}\right)_{\Sigma 1.00}\left(\mathrm{Ti}_{2.55} \mathrm{Fe}^{3+}{ }_{1.29} \mathrm{Nb}_{0.16}\right)_{\Sigma 4.00} \mathrm{Si}_{3.91} \mathrm{O}_{22}$ based on 13 cations per formula unit. Infrared spectra of unannealed crystals suggest significant radiation-induced damage. The structures of two unannealed crystals were refined, but there are major discrepancies $(\sim 13 \%)$ between the sums of the site-scattering values at the octahedrally coordinated $M$ sites and the analogous values calculated from the chemical compositions determined by electron-microprobe analysis. These discrepancies were not present when data were collected on annealed crystals, indicating that the original crystals are partly metamict and that this can significantly affect the results of site-scattering refinement. In the crystal structure of chevkinite, there are two distinct $\left(\mathrm{SiO}_{4}\right)$ tetrahedra that share one vertex to form an $\left[\mathrm{Si}_{2} \mathrm{O}_{7}\right]$ group: $<\mathrm{Si}-\mathrm{O}>=1.614\left(2^{a n}\right)$ and $1.612\left(3^{a n}\right) \AA,<\operatorname{Si}(1)-$ $\mathrm{O}(8)-\mathrm{Si}(2)>=172.0^{\circ}\left(2^{a n}\right)$ and $170.6^{\circ}\left(3^{a n}\right)$. There are four octahedrally coordinated $M$ sites that are occupied by small- to medium-sized divalent to pentavalent cations. The $M(1)$ site is occupied dominantly by $\mathrm{Fe}^{2+}$ with minor $\mathrm{Mn}^{2+}$, and the $M(2), M(3)$ and $M(4)$ sites are occupied by $\mathrm{Ti}, \mathrm{Fe}^{3+}$ and $\mathrm{Nb}$. There are two $A$-sites that are occupied by REE and minor $\mathrm{Ca}$ and $\mathrm{Th}$, with $\angle A-$ $\mathrm{O}>=2.56\left(2^{a n}\right)$ and $2.55\left(3^{a n}\right)$ ([8]-coordinated) and $2.66\left(2^{a n}\right)$ and $2.55\left(3^{a n}\right) \AA$ ([10]-coordinated). There are two crystallographically distinct rutile-like chains of octahedra $([M(3)+M(4)]$ and $[M(2)+M(2)])$ that extend in the $b$ direction and link to form a layer of octahedra parallel to (001). The layers of octahedra link through $\left[\mathrm{Si}_{2} \mathrm{O}_{7}\right]$ groups to form a framework with two interstitial $A$ sites, $\mathrm{CN}=[8]$ and [10], in which Ce is dominant over other REE, Ca and Th.
\end{abstract}

Keywords: chevkinite-(Ce), Ti-silicate, crystal structure, Mongolia, radiation damage.

\section{SOMMAIRE}

Nous avons résolu la structure cristalline de la chevkinite-(Ce) recuite $(r e c)$, de formule idéale (TR, $\mathrm{Ca})_{4} \mathrm{Fe}^{2+}\left(\mathrm{Ti}^{2} \mathrm{Fe}^{3+}, \mathrm{Nb}\right)_{4}$ $\mathrm{Si}_{4} \mathrm{O}_{22}$, monoclinique, $\mathrm{C} 2 / m$, en utilisant un cristal (2rec $) a 13.400(1), b 5.7232(4), c 11.0573(9) \AA, \beta 100.537(2)^{\circ}, V 833.7(2) \AA^{3}$ et un autre (3 $\left.3^{r e c}\right) a 13.368(2), b 5.7243(6), c$ 11.041(1) $\AA, \beta$ 100.516(1) ${ }^{\circ}, V$ 830.7(2) $\AA^{3} ; Z=2$, provenant de la Mongolie, par méthodes directes, et nous l'avons affiné jusqu'à un résidu $R_{1}$ de 6.3 et $5.7 \%$ en utilisant 1287 et 1180 réflexions uniques $\left(\left|F_{0}\right|>\right.$

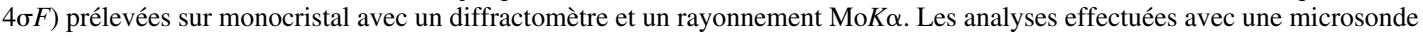

$\S$ E-mail address: elena_sokolova@umanitoba.ca 
électronique ont donné: cristal $\left(2^{\text {rec }}\right) \mathrm{SiO}_{2}$ 18.81, $\mathrm{TiO}_{2}$ 15.66, $\mathrm{FeO}$ 11.33, $\mathrm{MnO} 0.24, \mathrm{CaO} 1.61, \mathrm{Nb}_{2} \mathrm{O}_{5} 1.55, \mathrm{ThO}_{2} 0.40, \mathrm{Y}_{2} \mathrm{O}_{3}$ 0.30, $\mathrm{Ce}_{2} \mathrm{O}_{3}$ 23.45, $\mathrm{La}_{2} \mathrm{O}_{3}$ 13.92, $\mathrm{Nd}_{2} \mathrm{O}_{3}$ 6.88, $\mathrm{Pr}_{2} \mathrm{O}_{3}$ 1.95, $\mathrm{Sm}_{2} \mathrm{O}_{3}$ 0.51, $\mathrm{Gd}_{2} \mathrm{O}_{3}$ 0.42, $\mathrm{HfO}_{2}$ 0.01, $\mathrm{ZrO}_{2}$ 0.28, somme 97.32\% (poids), et cristal ( $3^{\text {rec }}$ ) $\mathrm{SiO}_{2}$ 18.53, $\mathrm{TiO}_{2}$ 16.11, $\mathrm{FeO} 12.62, \mathrm{MnO} 0.31, \mathrm{BaO} 0.02, \mathrm{CaO} 1.21, \mathrm{Nb}_{2} \mathrm{O}_{5} 1.69, \mathrm{ThO}_{2} 0.10, \mathrm{Y}_{2} \mathrm{O}_{3} 0.30$, $\mathrm{Ce}_{2} \mathrm{O}_{3}$ 24.30, $\mathrm{La}_{2} \mathrm{O}_{3}$ 12.94, $\mathrm{Nd}_{2} \mathrm{O}_{3}$ 8.13, $\mathrm{Pr}_{2} \mathrm{O}_{3}$ 2.44, $\mathrm{Sm}_{2} \mathrm{O}_{3}$ 0.82, $\mathrm{Gd}_{2} \mathrm{O}_{3}$ 0.36, $\mathrm{HfO}_{2}$ 0.16, $\mathrm{ZrO}_{2}$ 0.08, $\mathrm{Ta}_{2} \mathrm{O}_{5} 0.03, \mathrm{WO}_{3} 0.02$ somme $100.17 \%$. Les formules correspondantes sont: $\left(2^{\text {rec }}\right):\left(\mathrm{Ce}_{1.85} \mathrm{La}_{1.11} \mathrm{Nd}_{0.53} \mathrm{Pr}_{0.15} \mathrm{Sm}_{0.04} \mathrm{Gd}_{0.03} \mathrm{Ca}_{0.32} \mathrm{Th}_{0.02}\right)_{\Sigma 4.05}\left(\mathrm{Fe}^{2+}{ }_{0.85}\right.$ $\left.\mathrm{Mn}^{2+}{ }_{0.04} \mathrm{Zr}_{0.03} \mathrm{Y}_{0.03} \mathrm{Ca}_{0.05}\right)_{\Sigma 1.00}\left(\mathrm{Ti}_{2.54} \mathrm{Fe}^{3+}{ }_{1.19} \mathrm{Nb}_{0.15}\right)_{\Sigma 3.88} \mathrm{Si}_{4.06} \mathrm{O}_{22}$ et $\left(3^{\text {rec }}\right):\left(\mathrm{Ce}_{1.88} \mathrm{La}_{1.01} \mathrm{Nd}_{0.61} \operatorname{Pr}_{0.19} \mathrm{Sm}_{0.06} \mathrm{Gd}_{0.03} \mathrm{Ca}_{0.27} \mathrm{Y}_{0.03}\right.$ $\left.\mathrm{Th}_{0.01}\right)_{\Sigma 4.08}\left(\mathrm{Fe}^{2+}{ }_{0.93} \mathrm{Mn}_{0.06} \mathrm{Zr}_{0.01}\right)_{\Sigma 1.00}\left(\mathrm{Ti}_{2.55} \mathrm{Fe}^{3+}{ }_{1.29} \mathrm{Nb}_{0.16}\right)_{\Sigma 4.00} \mathrm{Si}_{3.91} \mathrm{O}_{22}$ sur une base de 13 cations par unité formulaire. Les spectres infrarouges des échantillons non chauffés indiquent la présence de dommage important dû à la radiation. Les structures de deux cristaux naturels ont été affinées, mais révèlent des différences importantes ( 13\%) entre les sommes des valeurs de la dispersion aux divers sites $M$ à coordinence octaédrique et les valeurs analogues calculées à partir des compositions chimiques déterminées par analyse à la microsonde électronique. Ces différences ne sont pas évidentes quand les données sont prises des mêmes cristaux recuits, indication que les cristaux étaient métamictes à l'origine et que cet état peut affecter largement les résultats de l'affinement de la dispersion associée aux divers sites. Dans la structure de la chevkinite, deux tétraèdres $\left(\mathrm{SiO}_{4}\right)$ distincts partagent un vertex pour former un groupe $\left[\mathrm{Si}_{2} \mathrm{O}_{7}\right]:\langle\mathrm{Si}-\mathrm{O}\rangle=1.614\left(2^{\text {rec }}\right)$ et $1.612\left(3^{\text {rec }}\right) \AA,\langle\mathrm{Si}(1)-\mathrm{O}(8)-\mathrm{Si}(2)\rangle=172.0^{\circ}$ $\left(2^{\text {rec }}\right)$ et $170.6^{\circ}\left(3^{\text {rec }}\right)$. Il y a quatre sites $M$ à coordinence octaédrique, qu'occupent des cations de petite taille ou de taille moyenne, bivalents à pentavalents. Le site $M(1)$ contient surtout le $\mathrm{Fe}^{2+}$ avec une proportion mineure de $\mathrm{Mn}^{2+}$, et $M(2), M(3)$ et $M(4)$ sont les sites de $\mathrm{Ti}, \mathrm{Fe}^{3+}$ et $\mathrm{Nb}$. Il y a deux sites $A$ où logent les terres rares (TR) et des quantités moindres de $\mathrm{Ca}$ et de $\mathrm{Th}$, avec $<A-$ $\mathrm{O}>=2.56\left(2^{\text {rec }}\right)$ et $2.55\left(3^{\text {recc }}\right)$ (à coordinence [8]), et $2.66\left(2^{\text {rec }}\right)$ et $2.55\left(3^{\text {rec }}\right) \AA ̊$ (à coordinence [10]). La structure contient deux chaînes distinctes d'octaèdres de type rutile $([M(3)+M(4)]$ et $[M(2)+M(2)])$ allongées selon $b$ et liées pour former une couche d'octaèdres parallèles à (001). Ces couches sont liées gràce au groupes $\left[\mathrm{Si}_{2} \mathrm{O}_{7}\right]$ pour former une trame ayant deux sites interstitiels $A$, à coordinence [8] et [10], dans lequel le Ce prédomine par rapport aux autres terres rares, Ca et $\mathrm{Th}$.

(Traduit par la Rédaction)

Mots-clés: chevkinite-(Ce), silicate de Ti, structure cristalline, Mongolie, dommage dû à la radiation.

\section{INTRODUCTION}

Chevkinite-(Ce) is an accessory mineral in pegmatites associated with alkali granites and syenites; it is particularly common in associated contact-metasomatic rocks. Originally, chevkinite-(Ce) was described as perrierite by Bonatti \& Gottardi (1950). Peng \& Bun (1964) proposed a crystal-structure model for chevkinite-(Ce) based on structural data for perrierite-(Ce), ideally $\mathrm{Ce}_{4} \mathrm{Fe}^{2+}\left(\mathrm{Ti}^{4+}, \mathrm{Fe}\right)_{4} \mathrm{Si}_{4} \mathrm{O}_{22}$ (Gottardi 1960). Chevkinite-(Ce) (space group $C 2 / m$ ) and perrierite-(Ce) (space group $P 2{ }_{1} / a$ ) are dimorphs. Calvo \& Faggiani (1974) presented crystal-structure models for synthetic analogues of chevkinite-(Ce) and perrierite-(Ce). [We note that perrierite was redefined as perrierite- $(\mathrm{Ce})$ by Nickel \& Mandarino (1987)]. Usually, chevkinite-(Ce) is highly metamict, accounting for the problem in adequately characterizing its crystal structure. In addition to chevkinite-(Ce), there are two more minerals of the chevkinite-(Ce) structure-type: strontiochevkinite, ideally $(\mathrm{Sr}, \mathrm{REE})_{4} \mathrm{Fe}^{2+}\left(\mathrm{Ti}^{4+}, \mathrm{Fe}\right)_{4} \mathrm{Si}_{4} \mathrm{O}_{22}$ (Haggerty \& Mariano 1983) and polyakovite-(Ce), ideally $\mathrm{Ce}_{4} \mathrm{Mg}$ $\mathrm{Cr}^{3+}{ }_{2} \mathrm{Ti}^{4+}{ }_{2} \mathrm{Si}_{4} \mathrm{O}_{22}$ (Popov et al. 2001), and two more minerals of the perrierite-(Ce) structure-type, rengeite, ideally $\mathrm{Sr}_{4} \mathrm{Zr} \mathrm{Ti}_{4} \mathrm{Si}_{4} \mathrm{O}_{22}$ (Miyajima et al. 2001) and matsubaraite, $\mathrm{Sr}_{4} \mathrm{Ti}_{5} \mathrm{Si}_{4} \mathrm{O}_{22}$ (Miyajima et al. 2002). The crystal structures of strontiochevkinite and rengeite are not yet fully characterized. They were assigned to the chevkinite-(Ce) and perrierite-(Ce) structure types in accord with the $\beta$ angle: $100.32^{\circ}$ for strontiochevkinite and $114.26^{\circ}$ for rengeite, as Haggerty \& Mariano (1983) regarded the $\beta$ angle as being the best way of distin- guishing chevkinite- $(\mathrm{Ce})\left(\beta \approx 100^{\circ}\right)$ from perrierite(Ce) $\left(\beta \approx 113^{\circ}\right)$. Usually, chevkinite-(Ce), strontiochevkinite, polyakovite-(Ce) and perrierite-(Ce) are highly metamict. Occurrences of non-metamict chevkinite-(Ce) (Kovalenko et al. 1995) and perrierite(Ce) (Parodi et al. 1994) have been reported. Rengeite is very poor in $\mathrm{U}$ and $\mathrm{Th}$, and matsubaraite does not contain any $\mathrm{U}$ and $\mathrm{Th}$; both minerals are thus crystalline, and give excellent X-ray powder-diffraction data from unannealed material (Miyajima et al. 2001, 2002). Kovalenko et al. (1995) described crystalline chevkinite-(Ce) from the Tsahirin-Khuduk $\mathrm{Zr}-\mathrm{Nb}-\mathrm{REE}$-ore occurrence at the northernmost part of the Northern outcrop of the Khaldzan Buragtag alkali granite, Mongolian Altay, Western Mongolia. The sample was collected from the pegmatitic zone of the alkali granite Geophysicheskii, in which chevkinite-(Ce) forms wellshaped prismatic crystals up to $1.0 \times 0.2 \times 0.1 \mathrm{~cm}$. Associated minerals are orthoclase, riebeckite, quartz, fergusonite-(Y), Ta-rich fersmite and zircon. These crystals of chevkinite-(Ce) appear unaltered and do not contain any visible products of later metasomatic alteration. Chevkinite-(Ce) crystals from metasomatic assemblages are usually surrounded by a crust of secondary minerals: allanite-(Ce) , Nb-bearing ilmenite, rutile, synchysite- $(\mathrm{Ce})$ and cerite- $(\mathrm{Ce})$ (Kartashov 1994). Yang et al. (2002) reported on the structure of a sample of Fe-rich chevkinite-(Ce) from Mianning, Sichuan Province, China. Here we report results of a single-crystal study of chevkinite-(Ce), focusing on the effect of moderate radiation-damage on site-occupancy refinement, and we discuss two possible assignments of 
site populations and the crystal chemistry of the chevkinite-group minerals. The superscript $a n$ indicates that a crystal was annealed in air for 3 hours at $1100^{\circ} \mathrm{C}$.

\section{Single-Crystal X-Ray Diffraction}

\section{Collection of X-ray data}

Four sets of single-crystal X-ray data were collected for three crystals of chevkinite-(Ce). Crystals (1) and $\left(2^{a n}\right)$ were mounted on an automated four-circle $P 4$ diffractometer fitted with a CCD detector [1K SMART for crystal (1), 4K APEX for crystal $\left.\left(2^{a n}\right)\right]$ and equipped with a MoK $\alpha \mathrm{X}$-ray source. Integrated intensities were collected up to $2 \theta \approx 60^{\circ}$, using $60 \mathrm{~s}$ per frame, $0.2^{\circ}$ framewidths, and crystal-detector distances of 4 and 5 $\mathrm{cm}$ for the $1 \mathrm{~K}$ and $4 \mathrm{~K}$ detectors, respectively. The refined cell-parameters (Table 1) were obtained from 4393 and 4103 reflections $(I>10 \sigma I)$. An empirical absorption correction (SADABS, Sheldrick 1998) was applied. Crystals (2) and $\left(3^{a n}\right)$ were mounted on a $P 3$ automated four-circle diffractometer fitted with a serial detector and using $\operatorname{Mo} K \alpha \mathrm{X}$-radiation. Cell parameters were determined from 16 reflections with $7 \leq 2 \theta \leq 25^{\circ}$. Integrated intensities of 1450 and 1393 reflections with $\overline{18} \leq h \leq 18,0 \leq k \leq 8,0 \leq l \leq 15$ were collected up to $2 \theta$ $=60.12^{\circ}$ according to the procedure of Hawthorne $\&$ Groat (1985). An empirical absorption-correction using $\Psi$-scan data was applied, and the data were corrected for Lorentz, polarization and background effects.

\section{INFRARED SPECTROSCOPY}

Infrared spectra were collected on single grains of chevkinite-(Ce) using an Hyperion IR microscope interfaced with a Bruker Tensor 27 FTIR spectrometer fitted with a liquid-nitrogen-cooled mercury-cadmiumtelluride detector. Single crystals were positioned on the microscope stage and the aperture was reduced to include only a single crystal. Thirty-two scans were collected on each of three crystals, and scans for each crystal were combined at $4 \mathrm{~cm}^{-1}$ resolution from 4000 to $800 \mathrm{~cm}^{-1}$.

\section{Chemical Analysis}

The crystals used for X-ray diffraction were mounted in a perspex disc, ground, polished and coated with carbon for chemical analysis using a Cameca SX-50 electron microprobe. Ten points were analyzed on each crystal using the following conditions: excitation voltage: $15 \mathrm{kV}$, specimen current: $20 \mathrm{nA}$, beam size $5 \mu \mathrm{m}$. The following standards and crystals were used: diopside: $\mathrm{Si}, \mathrm{Ca}$, titanite: $\mathrm{Ti}$, spessartine: $\mathrm{Mn}$, fayalite: $\mathrm{Fe}$, $\mathrm{MnNb}_{2} \mathrm{O}_{6}: \mathrm{Nb}, \mathrm{LaPO}_{4}: \mathrm{La}, \mathrm{CePO}_{4}: \mathrm{Ce}, \mathrm{NdPO}_{4}: \mathrm{Nd}$, REE3: YiPr, REE2*: Sm, REE1*: Gd [REE 1-3: synthetic $\mathrm{Ca}-\mathrm{Al}$-silicate glasses to which 3-4 wt.\% REE has been added (Drake \& Weill 1972)], chromite: $\mathrm{Cr}$, $\mathrm{ZrSiO}_{4}: \mathrm{Zr}$, barite: $\mathrm{Ba}, \mathrm{HfSiO}_{4}$ : $\mathrm{Hf}, \mathrm{CaWO}_{4}: \mathrm{W}, \mathrm{ThO}_{2}$ : $\mathrm{Th}, \mathrm{UO}_{2}$ : U, manganotantalite: Ta. The formulae (Table 2) were calculated on the basis of 13 cations per

\begin{tabular}{|c|c|c|c|c|}
\hline & (1) & $(2)$ & $\left(2^{2 n}\right)$ & $\left(3^{a n}\right)$ \\
\hline$a(\AA)$ & $13.4319(8)$ & $13.534(3)$ & $13.400(1)$ & $13.368(2)$ \\
\hline$b$ & $5.7628(3)$ & $5.789(1)$ & $5.7232(4)$ & $5.7243(6)$ \\
\hline$c$ & $11.0914(7)$ & $11.159(2)$ & $11.0573(9)$ & $11.041(1)$ \\
\hline$\beta\left(^{\circ}\right)$ & $100.629(1)$ & $100.57(2)$ & $100.537(2)$ & $100.516(1)$ \\
\hline$V\left(\AA^{3}\right)$ & $843.8(1)$ & $859.5(3)$ & $833.7(2)$ & $830.7(2)$ \\
\hline Space group & $\mathrm{C} 2 / \mathrm{m}$ & $\mathrm{C} 2 / \mathrm{m}$ & $\mathrm{C} 2 / \mathrm{m}$ & $\mathrm{C} 2 / m$ \\
\hline z & 2 & 2 & 2 & 2 \\
\hline $\begin{array}{l}\text { Absorption } \\
\text { coefficient }\left(\mathrm{mm}^{-1}\right)\end{array}$ & 13.80 & 13.15 & 13.56 & 13.92 \\
\hline$F(000)$ & 1228.9 & 1147.1 & 1147.1 & 1157.7 \\
\hline$D$ (calc) $\left(\mathrm{g} \cdot \mathrm{cm}^{-3}\right)$ & 5.017 & 4.858 & 5.009 & 5.078 \\
\hline Crystal size (mm) & $0.08 \times 0.10 \times 0.12$ & $0.08 \times 0.08 \times 0.16$ & $0.06 \times 0.07 \times 0.16$ & $0.08 \times 0.10 \times 0.12$ \\
\hline Radiation & MoK $\alpha$ & MoK $\propto$ & MoK $\alpha$ & MoK $\alpha$ \\
\hline $\begin{array}{l}2 \theta \text {-range for } \\
\text { data collection }\left({ }^{\circ}\right)\end{array}$ & 60.06 & 60.12 & 59.98 & 60.12 \\
\hline$R($ int $)(\%)$ & 2.3 & 6.8 & 1.9 & 1.7 \\
\hline $\begin{array}{l}\text { Reflections collected } \\
\mid F(\text { obs }) \mid>4 \sigma F\end{array}$ & $\begin{array}{l}7154 \\
4325\end{array}$ & $\begin{array}{c}1450 \\
-\end{array}$ & $\begin{array}{l}5599 \\
3208\end{array}$ & $\begin{array}{c}1393 \\
-\end{array}$ \\
\hline $\begin{array}{l}\text { Unique reflections } \\
F \text { (obs) }>4 \sigma F\end{array}$ & $\begin{array}{l}1342 \\
1182\end{array}$ & $\begin{array}{l}1397 \\
1090\end{array}$ & $\begin{array}{l}1320 \\
1287\end{array}$ & $\begin{array}{l}1331 \\
1180\end{array}$ \\
\hline Refinement method & \multicolumn{4}{|c|}{ Full-matrix least-squares on $F^{2}$; fixed weights proportional to $1 / \sigma\left(F^{2}\right)$} \\
\hline Goodness of fit on $F^{2}$ & 1.15 & 1.12 & 1.24 & 1.13 \\
\hline $\begin{array}{l}\text { Final } R \text { index }(\%) \\
{\left[F_{0}>4 \sigma F\right]}\end{array}$ & 4.7 & 6.5 & 6.3 & 5.7 \\
\hline $\begin{array}{l}R \text { index (\%) (all data) } \\
W R^{2}\end{array}$ & $\begin{array}{r}5.3 \\
14.7\end{array}$ & $\begin{array}{r}8.0 \\
20.5\end{array}$ & $\begin{array}{r}6.5 \\
16.1\end{array}$ & $\begin{array}{r}6.1 \\
18.3\end{array}$ \\
\hline
\end{tabular}


TABLE 2. CHEMICAL COMPOSITION (wt.\%)* AND EMPIRICAL FORMULA (apfu) OF CHEVKINITE-(Ce)

\begin{tabular}{|c|c|c|c|c|c|c|c|c|c|}
\hline & (1) & (2) & $\left(2^{a n}\right)$ & $\left(3^{a n}\right)$ & & (1) & (2) & $\left(2^{a n}\right)$ & $\left(3^{a n}\right)$ \\
\hline $\mathrm{SiO}_{2}$ & 18.56 & 18.89 & 18.81 & 18.53 & $\mathrm{Si}$ & 3.99 & 4.01 & 4.06 & 3.91 \\
\hline $\mathrm{TiO}_{2}$ & 16.11 & 16.49 & 15.66 & 16.11 & & & & & \\
\hline $\mathrm{FeO}$ & 11.44 & 11.12 & 11.33 & 12.62 & $\mathrm{Ti}$ & 2.61 & 2.63 & 2.54 & 2.55 \\
\hline $\mathrm{MnO}$ & 0.31 & 0.27 & 0.24 & 0.31 & $\mathrm{Fe}^{3+}$ & 1.25 & 1.21 & 1.31 & 1.29 \\
\hline $\mathrm{CaO}$ & 1.11 & 1.64 & 1.61 & 1.21 & $\mathrm{Nb}$ & 0.14 & 0.16 & $\underline{0.15}$ & 0.16 \\
\hline $\mathrm{Nb}_{2} \mathrm{O}_{5}$ & 1.48 & 1.69 & 1.55 & 1.69 & $\Sigma$ & 4.00 & 4.00 & 4.00 & 4.00 \\
\hline $\mathrm{ThO}_{2}$ & n.d. & 0.48 & 0.40 & n.d. & & & & & \\
\hline $\mathrm{Y}_{2} \mathrm{O}_{3}$ & 0.28 & 0.31 & 0.30 & 0.30 & $\mathrm{Fe}^{2+}$ & 0.81 & 0.76 & 0.73 & 0.93 \\
\hline $\mathrm{Ce}_{2} \mathrm{O}_{3}$ & 24.37 & 23.48 & 23.45 & 24.30 & $\mathrm{Mn}^{2+}$ & 0.04 & 0.05 & 0.04 & 0.06 \\
\hline $\mathrm{La}_{2} \mathrm{O}_{3}$ & 13.59 & 14.18 & 13.92 & 12.94 & $\mathrm{Hf}$ & 0.01 & 0.01 & 0.00 & 0.00 \\
\hline $\mathrm{Nd}_{2} \mathrm{O}_{3}$ & 7.78 & 6.72 & 6.88 & 8.13 & $Z r$ & 0.01 & 0.03 & 0.03 & 0.01 \\
\hline $\mathrm{Pr}_{2} \mathrm{O}_{3}$ & 2.22 & 2.08 & 1.95 & 2.44 & $Y$ & 0.03 & 0.04 & 0.03 & 0.03 \\
\hline $\mathrm{Sm}_{2} \mathrm{O}_{3}$ & 0.72 & 0.64 & 0.51 & 0.82 & $\mathrm{Ca}$ & 0.10 & 0.11 & $\underline{0.16}$ & 0.00 \\
\hline $\mathrm{Gd}_{2} \mathrm{O}_{3}$ & 0.37 & 0.42 & 0.42 & 0.36 & $\Sigma$ & 1.00 & 1.00 & 0.99 & 1.03 \\
\hline $\mathrm{HfO}_{2}$ & 0.14 & 0.18 & 0.01 & 0.16 & & & & & \\
\hline $\mathrm{ZrO}_{2}$ & 0.08 & 0.28 & 0.28 & 0.08 & $\mathrm{Ce}$ & 1.92 & 1.83 & 1.85 & 1.88 \\
\hline \multirow[t]{8}{*}{ Total } & 98.56 & 98.873 & 97.32 & 100.00 & $\mathrm{La}$ & 1.08 & 1.11 & 1.11 & 1.01 \\
\hline & & & & & Nd & 0.60 & 0.51 & 0.53 & 0.61 \\
\hline & & & & & $\mathrm{Pr}$ & 0.17 & 0.16 & 0.15 & 0.19 \\
\hline & & & & & $\mathrm{Sm}$ & 0.05 & 0.05 & 0.04 & 0.06 \\
\hline & & & & & $\mathrm{Gd}$ & 0.03 & 0.03 & 0.03 & 0.03 \\
\hline & & & & & $\mathrm{Ca}$ & 0.16 & 0.26 & 0.21 & 0.27 \\
\hline & & & & & Th & - & $\underline{0.02}$ & 0.02 & - \\
\hline & & & & & $\Sigma$ & 4.01 & 3.97 & 4.00 & 4.05 \\
\hline
\end{tabular}

${ }^{*} \mathrm{Cr}, \mathrm{Mg}, \mathrm{Ba}, \mathrm{U}, \mathrm{Mg}, \mathrm{Ta}, \mathrm{W}$ not detected

formula unit, as this method does not require prior knowledge of the $\mathrm{Fe}^{3+}: \mathrm{Fe}^{2+}$ ratio of the crystal.

\section{Structure Solution and Refinement}

The crystal structure of chevkinite-(Ce) was solved by direct methods; the SHELXTL 5.1 system of programs (Sheldrick 1997) was used for solution and refinement of the structure. Scattering factors for neutral atoms were taken from the International Tables for XRay Crystallography (1992). Details of the structure refinement are given in Table 1. The crystal structure of chevkinite-(Ce) was refined to $R_{1}$ indices of $4.7-6.5 \%$ and a GoF of 1.12-1.24 for a total of 115 refined parameters. Residual weak maxima [about $2.5 e$ for crystal (1) and 3.5-4.2 $e$ for crystals (2), $\left(2^{a n}\right)$ and $\left.\left(3^{a n}\right)\right]$ were found to be present in difference-Fourier maps calculated at the final stages of refinement. Final atom parameters are given in Table 3 , selected interatomic distances are presented in Table 4, refined site-scattering values are given in Table 5, comparison of total $M$ scattering is given in Table 6, and bond-valence analyses of crystals $\left(2^{a n}\right)$ and $\left(3^{a n}\right)$ are shown in Table 7 . Struc- ture factors may be obtained from The Depository of Unpublished Data, CISTI, National Research Council, Ottawa, Ontario K1A 0S2, Canada.

\section{Description of the Structure}

\section{Coordination of the cations}

In the crystal structure of chevkinite-(Ce), there are two unique $\mathrm{Si}$ sites, each occupied by $\mathrm{Si}$ and surrounded by four $\mathrm{O}$ atoms in a tetrahedral arrangement. For crystals (1) and (2), $<$ Si(1) $-\mathrm{O}>$ varies from 1.620 to 1.625 $\AA$ and $<\operatorname{Si}(2)-\mathrm{O}>$ varies from 1.618 to $1.623 \AA$. For the annealed crystals $\left(2^{a n}\right)$ and $\left(3^{a n}\right),<\mathrm{Si}(1)-\mathrm{O}>$ varies between 1.612 and $1.614 \AA$, and $<\operatorname{Si}(2)-\mathrm{O}>$ varies between 1.616 and $1.609 \AA$. There are four $M$ sites, each coordinated by six $\mathrm{O}$ atoms in an octahedral arrangement and occupied by intermediate to small divalent to tetravalent cations. There are two $A$ sites $(\mathrm{CN}=[8]$ and [10]) occupied by REE, $\mathrm{Ca}$ and $\mathrm{Th}$. The interatomic distances vary from 2.469 to $2.811 \AA$ at $A(1)$ and 2.437 to 3.003 $\AA$ at $A(2)$. 


\section{Site-scattering refinement}

Solution and refinement of the structure of crystal (1) resulted in a major discrepancy between the number of electrons at the $M$ sites determined directly from sitescattering refinement and derived from the chemical composition determined by electron-microprobe analysis: there is a $10 \%$ difference between these two values (133.9 versus 122.1 epfu, respectively, Table 6). This difference is much larger than expected for these two methods (i.e., of the order of a few \%). Moreover, there was an unsatisfactory aspect to the unit formula in that the number of $M$-site cations is significantly less than 5 apfu whereas the number of large cations ( $r>0.9 \AA)$ is significantly greater than 4 apfu (Table 2). Moreover, this problem is not confined to the unit formula. The refined site-scattering value at the $M(1)$ site (Table 5) is 31.7 epfu, and yet the dominant cation at this site must be $\mathrm{Fe}$ (or $\mathrm{Ti}$ ) with only a small amount of $\mathrm{Nb}$ as a pos- sible constituent. The atomic number of $\mathrm{Fe}$ is 26 , and the $M(1)$ octahedron is too small to contain any REE cations; hence the refined site-scattering value at the $M(1)$ site is incompatible with the chemical composition of the crystal. These problems prompted us to repeat the X-ray and electron-microprobe data-collections on a second crystal [crystal (2)]. The results (Table 3b) for crystal (2) are very similar to those for crystal (1), and the problem with the high value of the refined scattering at the $M(1)$ site is even greater than that observed for crystal (1) (Table 5).

At this stage, we began to suspect that this sample of chevkinite-(Ce) is not completely crystalline, as partial metamictization can affect the X-ray scattering characteristics of crystals (e.g., Hawthorne et al. 1991). Examination of grains by transmission electron spectroscopy was unsuccessful owing to the very small grain-size, grain-shape and paucity of material. However, infrared spectroscopy was more revealing. The spectra of

TABLE 3. ATOM COORDINATES AND DISPLACEMENT PARAMETERS $\left(\AA^{2}\right)$ FOR CHEVKINITE-(Ce)

\begin{tabular}{|c|c|c|c|c|c|c|c|c|c|c|}
\hline & $x$ & $y$ & $z$ & $U_{11}$ & $U_{22}$ & $U_{33}$ & $U_{23}$ & $U_{13}$ & $U_{12}$ & $U_{\text {eq }}$ \\
\hline \multicolumn{11}{|c|}{ Crystal (1) } \\
\hline$A(1)$ & $0.35601(6)$ & 0 & $0.73503(7)$ & $0.0180(4)$ & $0.0181(4)$ & $0.0182(4)$ & 0 & $0.0036(3)$ & 0 & $0.0181(3)$ \\
\hline$A(2)$ & $0.06863(6)$ & 0 & $0.74067(7)$ & $0.0146(4)$ & $0.0366(5)$ & $0.0150(4)$ & 0 & $0.0037(3)$ & 0 & $0.0219(3)$ \\
\hline$M(1)$ & $1 / 2$ & 0 & $1 / 2$ & $0.0328(16)$ & $0.0188(13$ & $0.0137(12)$ & 0 & $0.0049(10)$ & 0 & $0.0217(9)$ \\
\hline$M(2)$ & $1 / 4$ & $1 / 4$ & 0 & $0.0175(10)$ & $0.0145(10)$ & $0.0130(10)$ & $-0.0002(7)$ & $0.0022(7)$ & $0.0005(7)$ & $0.0151(6)$ \\
\hline$M(3)$ & 0 & 0 & 0 & $0.0142(16)$ & $0.0155(16)$ & $0.0126(15)$ & 0 & $0.0045(11)$ & 0 & $0.0139(10)$ \\
\hline$M(4)$ & $1 / 2$ & 0 & 0 & $0.0184(13)$ & $0.0166(13)$ & $0.0171(13)$ & 0 & $0.0023(10)$ & 0 & $0.0175(6)$ \\
\hline$S i(1)$ & $0.2008(3)$ & $-1 / 2$ & $0.7312(3)$ & $0.0318(16)$ & $0.0272(15)$ & $0.0294(15)$ & 0 & $0.0067(12)$ & 0 & $0.0293(7)$ \\
\hline Si(2) & $0.3567(3)$ & $-1 / 2$ & $0.5465(3)$ & $0.0344(17)$ & $0.0319(17)$ & $0.0300(16)$ & 0 & $0.0069(13)$ & 0 & $0.0320(7)$ \\
\hline$O(1)$ & $0.4775(5)$ & $0.2539(12)$ & $0.8734(6)$ & $0.015(3)$ & $0.016(3)$ & $0.014(3)$ & $-0.003(2)$ & $0.004(2)$ & $-0.004(3)$ & $0.0149(13)$ \\
\hline$O(2)$ & $0.1460(7)$ & 0 & $0.9767(8)$ & $0.013(4)$ & $0.012(4)$ & $0.013(4)$ & 0 & $0.006(3)$ & 0 & $0.0121(17)$ \\
\hline$O(3)$ & $0.1843(8)$ & 0 & $0.5969(9)$ & $0.021(5)$ & $0.015(4)$ & $0.010(4)$ & 0 & $0.003(3)$ & 0 & $0.0154(18)$ \\
\hline$O(4)$ & $0.3479(7)$ & 0 & $0.9895(8)$ & $0.012(4)$ & $0.010(4)$ & $0.015(4)$ & 0 & $0.003(3)$ & 0 & $0.0122(17)$ \\
\hline$O(5)$ & $0.4245(6)$ & $0.2739(14)$ & $0.5973(7)$ & $0.030(4)$ & $0.019(4)$ & $0.019(3)$ & $0.002(3)$ & $-0.003(3)$ & $0.011(3)$ & $0.0235(16)$ \\
\hline$O(6)$ & $0.2285(6)$ & $-0.7349(12)$ & $0.8139(6)$ & $0.027(3)$ & $0.010(3)$ & $0.009(3)$ & $0.002(2)$ & $0.002(2)$ & $0.003(3)$ & $0.0151(13)$ \\
\hline$O(7)$ & $0.0818(8)$ & $-1 / 2$ & $0.6726(11)$ & $0.010(5)$ & $0.060(9)$ & $0.027(6)$ & 0 & $-0.001(4)$ & 0 & $0.033(3)$ \\
\hline $\mathrm{O}(8)$ & $0.2648(11)$ & $-1 / 2$ & $0.6237(12)$ & $0.033(7)$ & $0.068(10)$ & $0.024(6)$ & 0 & $0.023(5)$ & 0 & $0.040(3)$ \\
\hline \multicolumn{11}{|c|}{ Crystal (2) } \\
\hline$A(1)$ & $0.35496(9)$ & 0 & $0.73642(11)$ & $0.0304(6)$ & $0.0248(6)$ & $0.0308(6)$ & 0 & $0.0086(4)$ & 0 & $0.0283(4)$ \\
\hline$A(2)$ & $0.06918(8)$ & 0 & $0.74232(10)$ & $0.0242(6)$ & $0.0462(8)$ & $0.0254(6)$ & 0 & $0.0073(4)$ & 0 & $0.0316(4)$ \\
\hline$M(1)$ & $1 / 2$ & 0 & $1 / 2$ & $0.053(2)$ & $0.0286(17)$ & $0.0234(16)$ & 0 & $0.0095(13)$ & 0 & $0.0347(11)$ \\
\hline$M(2)$ & $1 / 4$ & $1 / 4$ & 0 & $0.0284(13)$ & $0.0204(13)$ & $0.0206(12)$ & $0.0003(9)$ & $0.0045(8)$ & $0.0005(9)$ & $0.0231(8)$ \\
\hline$M(3)$ & 0 & 0 & 0 & $0.024(2)$ & $0.019(2)$ & $0.0222(2)$ & 0 & $0.0085(15)$ & 0 & $0.0209(13)$ \\
\hline$M(4)$ & $1 / 2$ & 0 & 0 & $0.0301(19)$ & $0.0215(17)$ & $0.0277(19)$ & 0 & $0.0041(15)$ & 0 & $0.0266(8)$ \\
\hline Si(1) & $0.2020(3)$ & $-1 / 2$ & $0.7317(4)$ & $0.041(2)$ & $0.0303(19)$ & $0.040(2)$ & 0 & $0.0088(17)$ & 0 & $0.0370(9)$ \\
\hline Si(2) & $0.3576(4)$ & $-1 / 2$ & $0.5470(4)$ & $0.046(2)$ & $0.041(2)$ & $0.038(2)$ & 0 & $0.0093(18)$ & 0 & $0.0416(10)$ \\
\hline$O(1)$ & $0.4776(6)$ & $0.2532(16)$ & $0.8744(8)$ & $0.023(4)$ & $0.026(4)$ & $0.020(4)$ & $-0.005(3)$ & $0.0078(3)$ & $-0.006(3)$ & $0.0223(17)$ \\
\hline $\mathrm{O}(2)$ & $0.1468(9)$ & 0 & $0.9786(11)$ & $0.021(6)$ & $0.017(5)$ & $0.023(6)$ & 0 & $0.006(5)$ & 0 & $0.020(2)$ \\
\hline$O(3)$ & $0.1827(11)$ & 0 & $0.5957(12)$ & $0.036(7)$ & $0.019(6)$ & $0.019(6)$ & 0 & $0.008(5)$ & 0 & $0.025(3)$ \\
\hline $\mathrm{O}(4)$ & $0.3486(9)$ & 0 & $0.9886(11)$ & $0.024(6)$ & $0.019(6)$ & $0.019(6)$ & 0 & $0.005(5)$ & 0 & $0.021(2)$ \\
\hline$O(5)$ & $0.4247(8)$ & $0.273(2)$ & $0.5985(9)$ & $0.040(6)$ & $0.037(6)$ & $0.031(5)$ & $0.003(4)$ & $-0.005(4)$ & $0.0172(5)$ & $0.037(2)$ \\
\hline $\mathrm{O}(6)$ & $0.2286(7)$ & $-0.7354(14)$ & $0.8138(7)$ & $0.036(5)$ & $0.010(3)$ & $0.012(3)$ & $0.000(3)$ & $0.004(3)$ & $0.003(3)$ & $0.0193(16)$ \\
\hline$O(7)$ & $0.0831(11)$ & $-1 / 2$ & $0.6737(18)$ & $0.016(7)$ & $0.083(15)$ & $0.053(11)$ & 0 & $-0.004(7)$ & 0 & $0.052(5)$ \\
\hline$O(8)$ & $0.2654(15)$ & $-1 / 2$ & $0.6254(17)$ & $0.044(10)$ & $0.083(15)$ & $0.039(9)$ & 0 & $0.030(8)$ & 0 & $0.053(5)$ \\
\hline
\end{tabular}




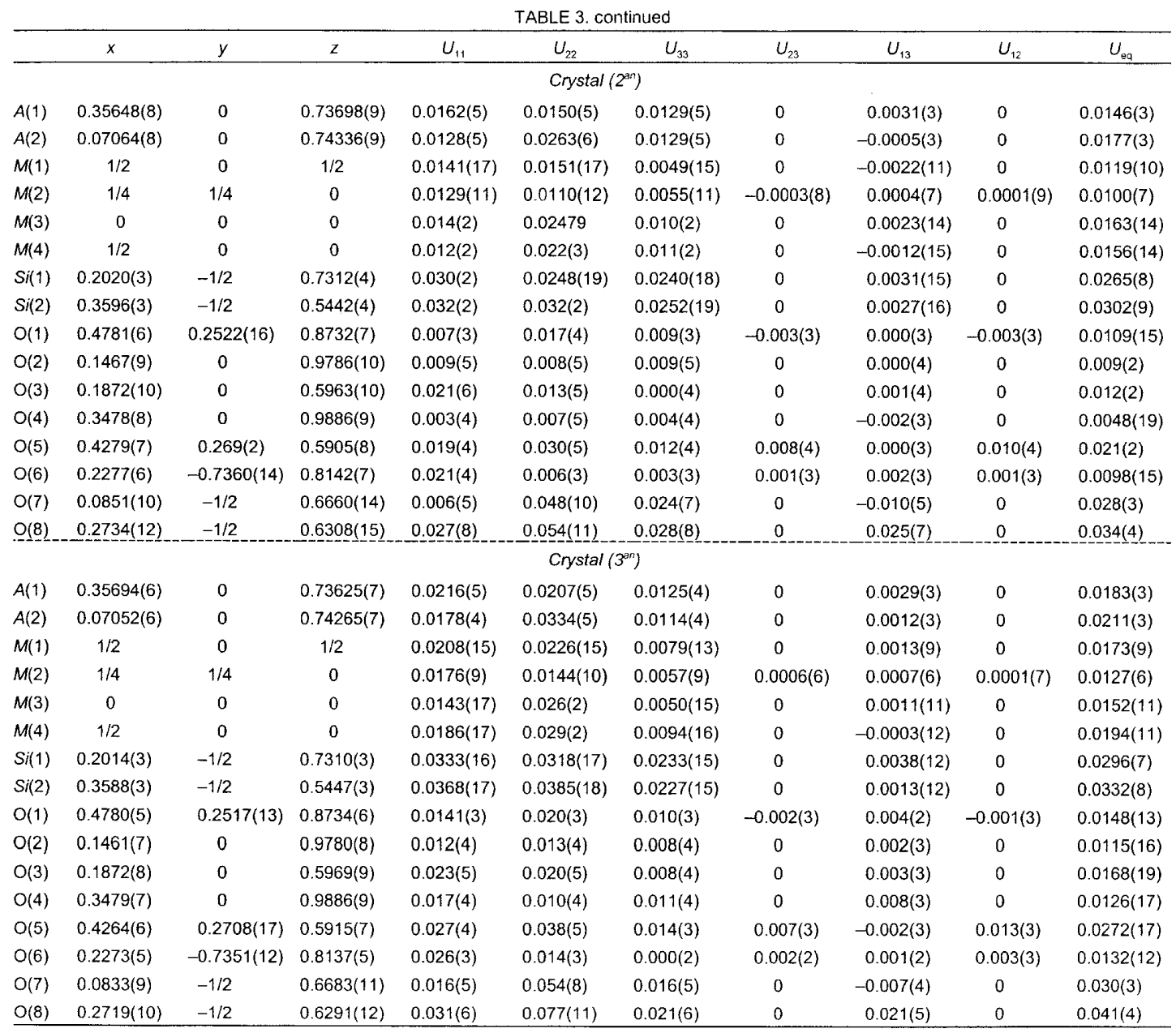

unannealed chevkinite-(Ce) (Fig. 1) shows a very strong absorption with a maximum at $\sim 3400 \mathrm{~cm}^{-1}$ and extending down to $\sim 2400 \mathrm{~cm}^{-1}$, with a very asymmetric envelope. This feature is very similar to absorption in partly metamict titanite (Hawthorne et al. 1991) and zircon (Aines \& Rossman 1986), which, like chevkinite-(Ce), are also nominally anhydrous minerals. The presence of small amounts of Th (and possibly U) in chevkinite(Ce) (Table 2) and the similarity of its infrared spectrum in the principal $\mathrm{OH}$-stretching region to those of metamict titanite and zircon suggest very strongly that the crystals of chevkinite-(Ce) examined here are partly metamict. Hence we annealed crystal (2) and a third crystal [crystals $\left(2^{a n}\right)$ and $\left(3^{a n}\right)$ ] in air for $3 \mathrm{~h}$ up to $1100^{\circ} \mathrm{C}$, and then repeated the data collection for these crystals. The refined site-scattering values at the $M$ sites are $128.2\left(2^{a n}\right)$ and $123.4\left(3^{a n}\right)$ epfu (Table 6) and the

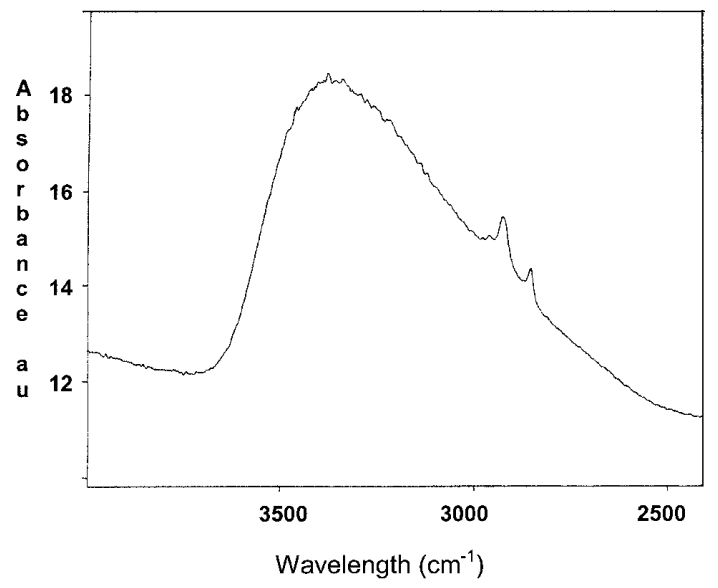

FIG. 1. Infrared-absorption spectrum of unannealed chevkinite-(Ce) 
CHEVKINITE-(Ce): CRYSTAL-STRUCTURE REFINEMENT

TABLE 4. SELECTED INTERATOMIC DISTANCES (A) AND ANGLES $\left({ }^{\circ}\right)$ IN CHEVKINITE--(Ce)

\begin{tabular}{|c|c|c|c|c|c|c|c|c|c|c|c|}
\hline & & (1) & (2) & $\left(2^{2 m}\right)$ & $\left(3^{a n}\right)$ & & & (1) & (2) & $\left(2^{3 r}\right)$ & $\left(3^{a n}\right)$ \\
\hline$A(1)-O(1)$ & $\times 2$ & $2.497(7)$ & $2.517(8)$ & $2.472(8)$ & $2.469(7)$ & $A(2)-\mathrm{O}(1)$ & $\times 2$ & $2.518(6)$ & $2.534(9)$ & $2.503(8)$ & $2.507(7)$ \\
\hline$A(1)-O(3)$ & & $2.522(10)$ & $2.561(14)$ & $2.505(12)$ & $2.498(11)$ & $A(2)-O(2)$ & & $2.633(9)$ & $2.653(13)$ & $2.614(11)$ & $2.610(9)$ \\
\hline$A(1)-O(4)$ & & $2.844(9)$ & $2.831(12)$ & $2.806(10)$ & $2.811(9)$ & $A(2)-O(3)$ & & $2.423(9)$ & $2.441(13)$ & $2.453(12)$ & $2.437(10)$ \\
\hline$A(1)-O(5)$ & $x 2$ & $2.488(8)$ & $2.507(12)$ & $2.546(10)$ & $2.522(9)$ & $A(2)-O(5)$ & $\times 2$ & $2.616(8)$ & $2.642(12)$ & $2.660(11)$ & $2.654(9)$ \\
\hline$A(1)-\mathrm{O}(6)$ & $x 2$ & $2.566(7)$ & $\underline{2.561(8)}$ & $2.555(8)$ & $2.565(7)$ & $A(2)-\mathrm{O}(6)$ & $\times 2$ & $2.639(7)$ & $2.647(9)$ & $2.593(9)$ & $2.590(7)$ \\
\hline \multirow[t]{2}{*}{$\langle A(1)-O\rangle$} & & 2.559 & 2.570 & 2.557 & 2.553 & $A(2)-\mathrm{O}(7)$ & $\times 2$ & $2.992(3)$ & $3.009(6)$ & $3.003(15)$ & $2.991(4)$ \\
\hline & & & & & & $\langle A(2)-O\rangle$ & & 2.659 & 2.676 & 2.659 & 2.653 \\
\hline$M(1)-O(5)$ & $\times 4$ & $2.256(8)$ & $2.271(11)$ & $2.159(10)$ & $2.181(9)$ & $M(2)-O(2)$ & $\times 2$ & $1.990(6)$ & $1.995(8)$ & $1.975(8)$ & $1.978(6)$ \\
\hline$M(1)-O(7)$ & $\times 2$ & $2.024(12)$ & $2.055(18)$ & $1.976(14)$ & $1.984(11)$ & $M(2)-O(4)$ & $\times 2$ & $1.968(6)$ & $1.988(8)$ & $1.960(7)$ & $1.958(6)$ \\
\hline \multirow[t]{2}{*}{$\langle M(1)-O>$} & & 2.179 & 2.199 & 2.098 & 2.115 & $M(2)-\mathrm{O}(6)$ & $\times 2$ & $2.033(6)$ & $2.046(7)$ & $2.023(1)$ & $2.025(6)$ \\
\hline & & & & & & $<M(2)-O\rangle$ & & 1.997 & 2.010 & 1.986 & 1.987 \\
\hline$M(3)-\mathrm{O}(1)$ & $x 4$ & $1.980(7)$ & $1.986(8)$ & $1.978(8)$ & $1.977(7)$ & $M(4)-\mathrm{O}(1)$ & $\times 4$ & $2.012(7)$ & $2.012(9)$ & $1.996(9)$ & $1.991(7)$ \\
\hline$M(3)-O(2)$ & $\times 2$ & $2.024(9)$ & $2.044(12)$ & $2.023(12)$ & $2.011(9)$ & $M(4)-O(4)$ & $x 2$ & $2.025(9)$ & $2.030(12)$ & $2.020(10)$ & $2.015(9)$ \\
\hline$\langle M(3)-O\rangle$ & & 1.995 & 2.005 & 1.993 & 1.988 & $\langle M(4)-\mathrm{O}\rangle$ & & 2.016 & 2.018 & 2.004 & 1.999 \\
\hline$S i(1)-O(6)$ & $x 2$ & $1.639(7)$ & $1.645(8)$ & $1.634(8)$ & $1.627(7)$ & $S i(1)-O(8)-S i(2)$ & & $163.8(1.1)$ & $164.1(1.5)$ & $172.0(1.3)$ & $170.6(1.1)$ \\
\hline $\mathrm{Si}(1)-\mathrm{O}(7)$ & & $1.610(12)$ & $1.621(16)$ & $1.600(13)$ & $1.605(11)$ & & & & & & \\
\hline$S i(1)-O(8)$ & & $1.593(11)$ & $1.587(16)$ & $1.593(14)$ & $1.594(11)$ & & & & & & \\
\hline$\langle S i(1)-O\rangle$ & & 1.620 & 1.625 & 1.612 & 1.614 & & & & & & \\
\hline$S i(2)-O(3)$ & & $1.585(10)$ & $1.585(14)$ & $1.565(12)$ & $1.573(11)$ & & & & & & \\
\hline$S i(2)-O(5)$ & $x 2$ & $1.629(8)$ & $1.640(11)$ & $1.635(10)$ & $1.623(9)$ & & & & & & \\
\hline$S i(2)-O(8)$ & & $1.627(12)$ & $1.650(16)$ & $1.629(14)$ & $1.617(12)$ & & & & & & \\
\hline$\langle\mathrm{Si}(2)-\mathrm{O}\rangle$ & & 1.618 & 1.623 & 1.616 & 1.609 & & & & & & \\
\hline
\end{tabular}

TABLE 5. REFINED SCATTERING VALUES (epfu) AND ASSIGNED SITE-POPULATIONS (apfu) FOR $M$-SITES IN CHEVKINITE-(Ce)

\begin{tabular}{|c|c|c|c|c|c|c|}
\hline & Crystal & $\begin{array}{l}\text { Refined site- } \\
\text { scattering }\end{array}$ & Assigned site-population & $\begin{array}{l}\text { Predicted } \\
\text { site-scattering }\end{array}$ & $\begin{array}{c}\langle M-O\rangle_{\text {calc }^{*}}{ }^{*} \\
(\AA)\end{array}$ & $\begin{array}{c}\angle M-O= \\
(\tilde{A})\end{array}$ \\
\hline \multirow{4}{*}{$M(1)$} & (1) & $3 \uparrow .7(4)$ & $\mathrm{np}^{+}$ & - & - & 2.179 \\
\hline & (2) & $35.3(6)$ & $\mathrm{np}^{*}$ & - & - & 2.201 \\
\hline & $\left(2^{a n}\right)$ & $28.2(5)$ & $0.85 \mathrm{Fe}^{2+}+0.05 \mathrm{Ca}+0.04 \mathrm{Mn}+0.03 \mathrm{Y}+0.03 \mathrm{Zr}$ & 26.5 & 2.150 & 2.098 \\
\hline & $\left(3^{a r}\right)$ & $27.2(4)$ & $0.93 \mathrm{Fe}^{2+}+0.06 \mathrm{Mn}^{2+}+0.01 \mathrm{Zr}$ & 26.1 & 2.163 & 2.115 \\
\hline \multirow{5}{*}{$M(2)$} & (1) & $53.2(6)$ & - & - & - & 1.997 \\
\hline & (2) & $55.7(7)$ & - & - & - & 2.010 \\
\hline & $\left(2^{\mathrm{an}}\right)$ & $54.5(7)$ & $1.19 \mathrm{Fe}^{3+}+0.57 \mathrm{Ti}+0.16 \mathrm{Nb}+0.08 \mathrm{\square}$ & 50.0 & 2.012 & 1.986 \\
\hline & $\left(3^{a n}\right)$ & $52.7(6)$ & $1.29 \mathrm{Fe}^{3+}+0.55 \mathrm{Ti}+0.16 \mathrm{Nb}$ & 52.2 & 2.014 & 1.987 \\
\hline & $\left(3^{a n}\right)^{*}$ & $52.7(6)$ & $1.00 \mathrm{Ti}+0.84 \mathrm{Fe}^{3+}+0.16 \mathrm{Nb}$ & 50.4 & 2.005 & 1.987 \\
\hline \multirow{4}{*}{$M(3)$} & (1) & $23.0(4)$ & - & - & - & 1.995 \\
\hline & (2) & $22.3(5)$ & - & - & - & 2.005 \\
\hline & $\left(2^{3 n}\right)$ & $23.5(6)$ & $1.00 \mathrm{Ti}$ & 22.0 & 1.985 & 1.993 \\
\hline & $\left(3^{a n}\right)$ & $21.2(4)$ & $1.00 \mathrm{Ti}$ & 22.0 & 1.985 & 1.988 \\
\hline \multirow{5}{*}{$M(4)$} & (1) & 26 & - & - & - & 2.016 \\
\hline & (2) & 26 & - & - & - & 2.018 \\
\hline & $\left(2^{a n}\right)$ & $22.0(6)$ & $1.00 \mathrm{Ti}$ & 22.0 & 1.985 & 2.004 \\
\hline & $\left(3^{a n}\right)$ & $22.3(5)$ & $1.00 \mathrm{Ti}$ & 22.0 & 1.985 & 1.999 \\
\hline & $\left(3^{\text {an }}\right)^{*}$ & $22.3(5)$ & $0.55 \mathrm{Ti}+0.45 \mathrm{Fe}^{3+}$ & 23.8 & 2.003 & 1.999 \\
\hline
\end{tabular}

not possible to assign site-populations as there is insufficient scattering in the formulae (Table 2);

"* calculated by summing the constituent ionic radii using values from Shannon (1976)

analogous values derived from the unit formula are $118.8\left(2^{a n}\right)$ and 122.3 epfu $\left(3^{a n}\right)$, differences of 7.9 and $1.1 \%$, respectively. Also, the refined scattering values at the $M(1)$ sites (Table 5) are $28.2\left(2^{a n}\right)$ and $27.2\left(3^{a n}\right)$ epfu, much less than the values of 31.7 and 35.3 epfu for crystals (1) and (2), and more in accord with the constituent $M$-site cations available for assignment to this site. 
The valence state of $\mathrm{Fe}$

The chemical formulae of crystals $\left(2^{a n}\right)$ and $\left(3^{a n}\right)$ (Table 2) leave us with a residual problem: the resultant structures have net positive charges of $2.97^{+}$and $3.37^{+}$ to be assigned to $1.31\left(2^{a n}\right)$ and $1.29 \mathrm{Fe}\left(3^{a n}\right)$ at the $M(2,3,4)$ sites. This results in contents of $\left(\mathrm{Ti}^{4+}{ }_{2.54}\right.$ $\left.\mathrm{Fe}^{3+}{ }_{0.35} \mathrm{Fe}^{2+}{ }_{0.96} \mathrm{Nb}_{0.15}\right)$ and $\left(\mathrm{Ti}^{4+}{ }_{2.55} \mathrm{Fe}^{3+}{ }_{0.79} \mathrm{Fe}^{2+}{ }_{0.50}\right.$ $\left.\mathrm{Nb}_{0.16}\right)$ for crystals $\left(2^{a n}\right)$ and $\left(3^{a n}\right)$, respectively. We may also examine the possible oxidation state of $\mathrm{Fe}$ at these sites via the hard-sphere model relating mean bondlength and constituent ionic radius. Although this model is not highly accurate in an absolute sense, it can give a reasonable indication of site constituents, particularly

\begin{tabular}{ccccc}
\multicolumn{5}{c}{ TABLE 6. COMPARISON OF } \\
\multicolumn{4}{c}{ TOTAL M-SITE SCATTERING VALUES (epfu) } \\
FROM SREF AND EMPA \\
\hline$(1)$ & $(2)$ & $\left(2^{\text {an }}\right)$ & $\left(3^{\text {an }}\right)$ \\
\hline$\sum M^{\text {SREF }}$ & 133.9 & 139.3 & 128.2 & 123.4 \\
$\Sigma M^{\text {EMPA }}$ & 122.1 & 118.8 & 118.8 & 122.3 \\
\hline
\end{tabular}

where the potential differences in size involved (i.e., $0.645 \AA$ for $\mathrm{Fe}^{3+}$ and $0.78 \AA$ for $\mathrm{Fe}^{2+}$ ) are substantial. We will consider three models: (1) all $\mathrm{Fe}^{3+}$, (2) $\mathrm{Fe}^{3+}$ : $\mathrm{Fe}^{2+}$ required for electroneutrality (see above), and (3) all $\mathrm{Fe}^{2+}$. The mean coordination of anions (calculated from Table 7) is [3.5], giving a mean anion radius of $1.37 \AA$ (Shannon 1976). The resulting calculations for crystal $\left(3^{a n}\right)$ are shown in Table 8 [those for crystal $\left(2^{a n}\right)$ are fairly similar]. The closest agreement occurs for an all-Fe ${ }^{3+}$ model, agreement for a neutral model is (just about) acceptable, whereas the agreement for the all$\mathrm{Fe}^{2+}$ model is not sufficiently close for this model to be considered acceptable.

\section{Assignment of site populations}

We will assign site populations for crystals $\left(2^{a n}\right)$ and $\left(3^{a n}\right)$, for which there is better agreement between the refined site-scattering values and the analogous values calculated from the unit formulae. The $M(1)$ octahedron is large (2.098 and $2.115 \AA$ ) and the remaining octahedra are small (1.994 and $1.991 \AA)$, indicating that Ti

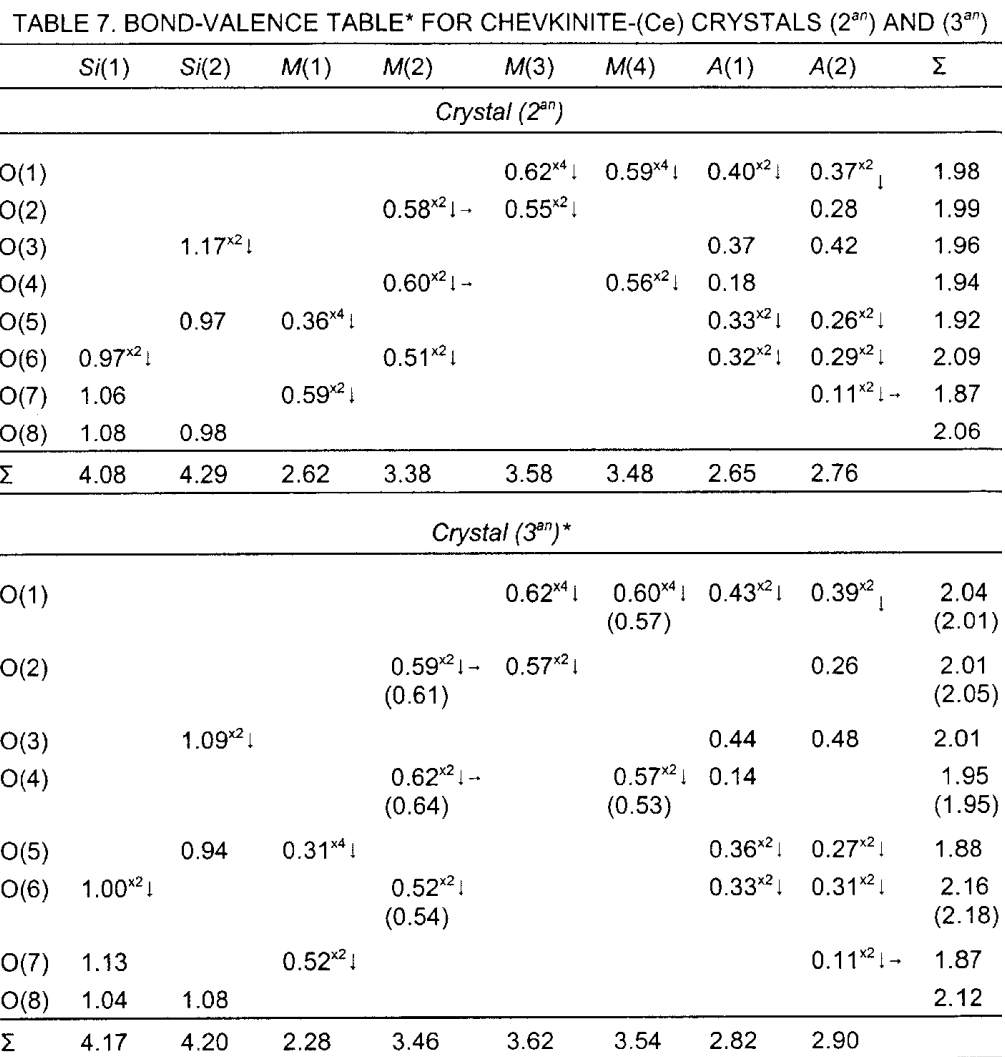

* Bond-valence curves ( $v u$ ) from Brown (1981);

values in parentheses are for the site populations labelled $\left(3^{\text {an }}\right)^{\star}$ in Table 5. 
occurs at $M(2,3,4)$ and not at $M(1)$. This assignment is also in accord with the refined site-scattering values at these sites (Table 5). The large size of the $M(1)$ octahedron indicates that the $M(1)$ site must be dominated by the divalent cations of the unit formula. Moreover, the fact that the refined scattering at $M(1)$ exceeds 26 epfu, the scattering value for $\mathrm{Fe}^{2+}$, indicates that the small amounts of large heavy cations in the structure (i.e., $\mathrm{Zr}$ and $\mathrm{Y}$ ) must occur at the $M(1)$ site. The predicted mean bond-lengths for the $M(1)$ site in crystals $\left(2^{a n}\right)$ and $\left(3^{a n}\right)$ are significantly greater $(2.150$ and $2.163 \AA$ ) than the corresponding observed values (2.098 and $2.115 \AA$ ), suggesting that some of the $\mathrm{Fe}$ at the $M(1)$ site may be $\mathrm{Fe}^{3+}: 0.54 \mathrm{Fe}^{2+}+0.31 \mathrm{Fe}^{3+}$ for crystal $\left(2^{a n}\right)$, and 0.69 $\mathrm{Fe}^{2+}+0.24 \mathrm{Fe}^{3+}$ for crystal $\left(3^{a n}\right)$. These values produce an even larger excess positive charge on the formulae than already caused by the assignment of all $\mathrm{Fe}$ as $\mathrm{Fe}^{3+}$ at the $M(2,3,4)$ sites, indicating that there are still residual-damage effects in the annealed structures.

The $M(2,3,4)$ sites have refined site-scattering values of 54.5(7), 23.5(6) and 22.0(6) for crystal $\left(2^{a n}\right)$ and of 52.7(6), 21.2(4) and 22.3(5) for crystal $\left(3^{a n}\right)$ epfu, respectively (Table 5), indicating that the strongest scatterers at these sites (i.e., $\mathrm{Nb}$ and $\mathrm{Fe}^{3+}$ ) must be assigned to the $M(2)$ site. This is in accord with the observation that the refined site-scattering values at the $M(3)$ and $M(4)$ sites are 23.5(6) and 22.0(6) for crystal ( $\left.2^{a n}\right)$, and 21.2 and 22.3 epfu for crystal $\left(3^{a n}\right)$, respectively, and in accord with these two sites being completely occupied by $\mathrm{Ti}$. The resulting site-populations for the $M(2,3,4)$ sites [labeled $\left(2^{a n}\right)$ and $\left(3^{a n}\right)$ in Table 5] show close agreement for the site-scattering values but significant differences between the observed and calculated mean bond-lengths at the $M(2)$ and $M(4)$ sites: e.g., $\Delta=0.5$ and $0.3 e p f u$, and $\Delta^{\prime}=0.027$ and $0.014 \AA$, respectively, for crystal $\left(3^{a n}\right)$, where $\Delta$ is the difference between the refined and EMPA site-scattering values, and $\Delta^{\prime}$ is the difference between the observed and calculated mean bond-lengths. An alternative site-assignment is given for the $M(2)$ and $M(4)$ sites [labeled $\left(2^{a n}\right)$ and $\left(3^{a n}\right)^{\prime}$ in Table 5]. Here, $\Delta=2.3$ and 1.5 epfu, and $\Delta^{\prime}=0.018$ and 0.004 $\AA$, respectively for crystal $\left(3^{a n}\right)$; model (3) shows closer agreement with the refined site-scattering values, whereas model (3)' shows closer agreement with the observed mean bond-lengths. We find no compelling argument to prefer either assignment $\left(2^{a n}\right)$ or $\left(2^{a n}\right)^{\prime},\left(3^{a n}\right)$ or $\left(3^{a n}\right)^{\prime}$, and hence present both possibilities in Table 5 .

\begin{tabular}{|c|c|c|c|}
\hline & All Fe ${ }^{3+}$ & Neutral & All $\mathrm{Fe}^{2}$ \\
\hline$<r>(\AA)$ & 0.619 & 0.636 & 0.663 \\
\hline$<r>+r_{\text {anion }}(\AA)$ & 1.989 & 2.006 & 2.033 \\
\hline$\langle M(2,3,4)-\mathrm{O}>(\AA)$ & 1.990 & 1.990 & 1.990 \\
\hline$\Delta(\AA)$ & 0.001 & 0.016 & 0.043 \\
\hline
\end{tabular}

The effect of partial metamictization on site-scattering refinement

A comparison of the results of site-scattering refinement and electron-microprobe analysis for unannealed crystals (1) and (2) shows major and systematic differences. The total amount of refined scattering at the $M$ sites exceeds that indicated by the unit formula calculated from the chemical composition by $\sim 13 \%$, an amount considerably greater than that expected for these experimental methods. Annealing a crystal [i.e., crystals (2 and 3)] reduced this discrepancy, producing an agreement between the two methods of $\sim 7$ and $1 \%$ (Table 6) for crystals $\left(2^{a n}\right)$ and $\left(3^{a n}\right)$. These discrepancies are not uniformly distributed across all four of the $M$ sites in the unannealed crystals; in particular, the refined scattering at the $M(1)$ site is not possible, given the chemical composition of the crystal, and yet it is reproducible.

These observations indicate that small amounts of radiation damage can lead to erroneous site-scattering values (and hence erroneous site-populations), and that the effect is reproducible. It is rather intriguing that the site-scattering values are differentially affected by radiation damage; this finding implies that displacements (around the $M$ sites) associated with small amounts of radiation damage are significantly different for the $M(1)$ site than for the $M(2,3,4)$ sites. In this regard, Lian et al. (2003) reported that in ion-irradiated pyrochlore, anion disorder precedes cation disorder in the radiation-induced transition from an ordered-pyrochlore superstructure to a cation-disordered defect-fluorite structure-type. Thus there seems to be some evidence that radiationinduced disorder does not proceed homogeneously in all structures.

These results have two implications: (1) structural studies on crystals that are suspected of being slightly radiation-damaged should involve heating of the crystal prior to X-ray data collection to avoid this systematic error; (2) the diffraction data contain information on the atom displacements associated with radiation damage, although it is not yet clear how to extract more quantitative information than the qualitative conclusions that are reached here.

\section{Structure topology}

Subsequent to determination of the crystal structure of perrierite-(Ce) (Gottardi 1960), Peng \& Bun (1964) proposed a model for the crystal structure of chevkinite(Ce) of composition REE $\left._{3.47} \mathrm{Ca}_{0.74} \mathrm{Th}_{0.01}\right)_{\Sigma 4.22} \mathrm{Fe}^{2+}$ $\left(\mathrm{Ti}_{2.72} \mathrm{Fe}^{3+}{ }_{0.44} \mathrm{Fe}^{2+}{ }_{0.41} \mathrm{Al}_{0.33} \mathrm{Mg}_{0.08}\right)_{\Sigma 3.98}\left(\mathrm{O}_{7.92} \mathrm{OH}_{0.08}\right)$ $\left[\begin{array}{lll}\left(\mathrm{Si}_{1.855}\right. & \left.\mathrm{Al}_{0.145}\right)_{\Sigma 2.00} & \mathrm{O}_{7}\end{array}\right]_{2}$. They predicted a structure based on analysis of the $\mathrm{P}(u v w)$ map and reported the space group as $C 2 / \mathrm{m}$. Topologically, this model corresponds to the crystal structure determined for chevkinite-(Ce) in this work. 


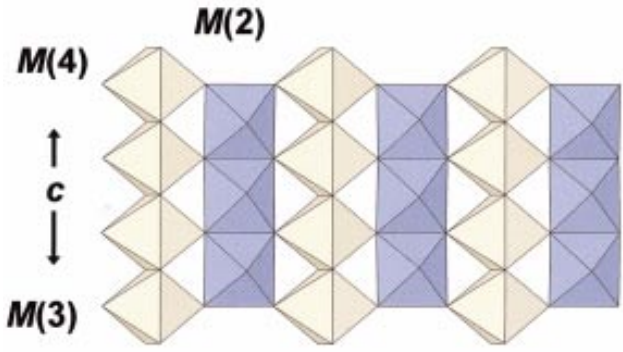

(a)

Chevkinite-(Ce),

assignment $\left(3^{\text {an }}\right)$

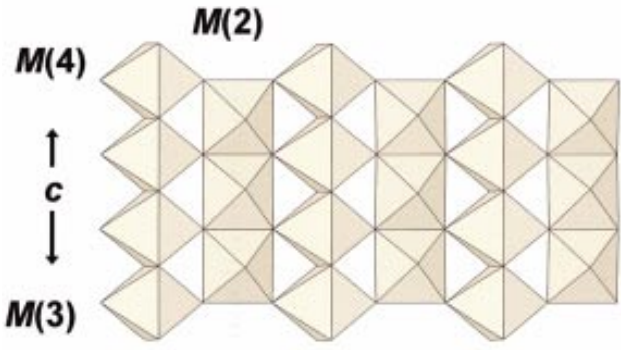

Chevkinite-(Ce),

(b)

assignment $\left(3^{\text {an }}\right)^{*}$

\section{Strontiochevkinite}

Perrierite-(Ce)

\section{Rengeite}

\section{Matsubaraite}

(c)

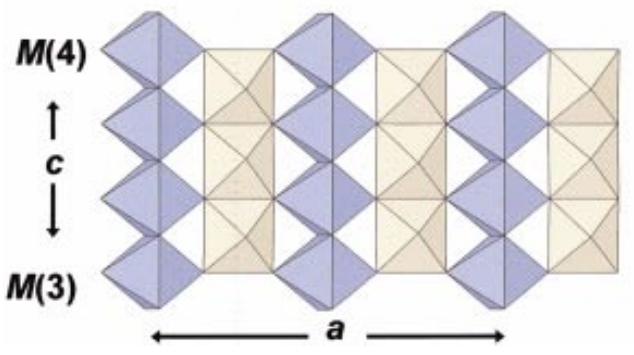

\section{Polyakovite-(Ce)}

FIG. 2. The layer of octahedra projected onto (001) (a) in chevkinite-(Ce), assignment ( $\left.3^{\text {an }}\right)$; (b) in chevkinite-(Ce), assignment $\left(3^{\text {an }}\right)^{*}$, strontiochevkinite, perrierite-(Ce), rengeite and matsubaraite; (c) in polyakovite- $(\mathrm{Ce})$. Tidominant octahedra are yellow, $\mathrm{Fe}^{3+}$-dominant octahedra in (a) and $\mathrm{Cr}^{3+}$ - dominant octahedra in (c) are blue.

a)

b)
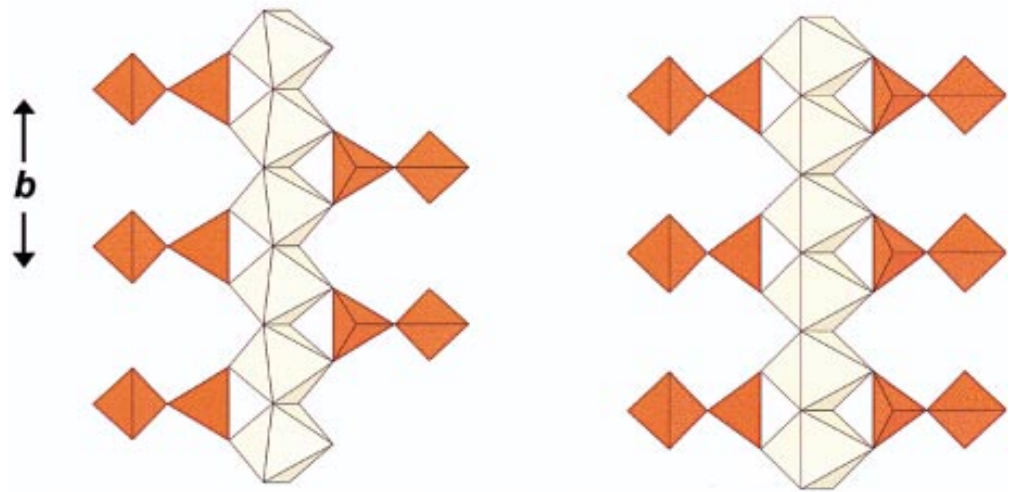

FIG. 3. Linkage of $\left(\mathrm{SiO}_{4}\right)$ tetrahedra and $M(2)$ octahedra in the crystal structure of (a) chevkinite-(Ce), assignment $\left(3^{a n}\right)^{*}$; (b) perrierite-(Ce). Legend as in Figure 1; $\left(\mathrm{SiO}_{4}\right)$ tetrahedra are orange. 


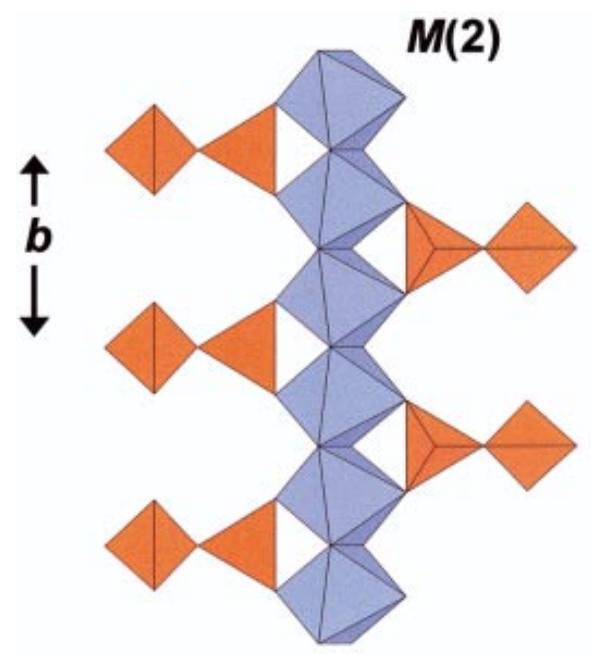

(a)

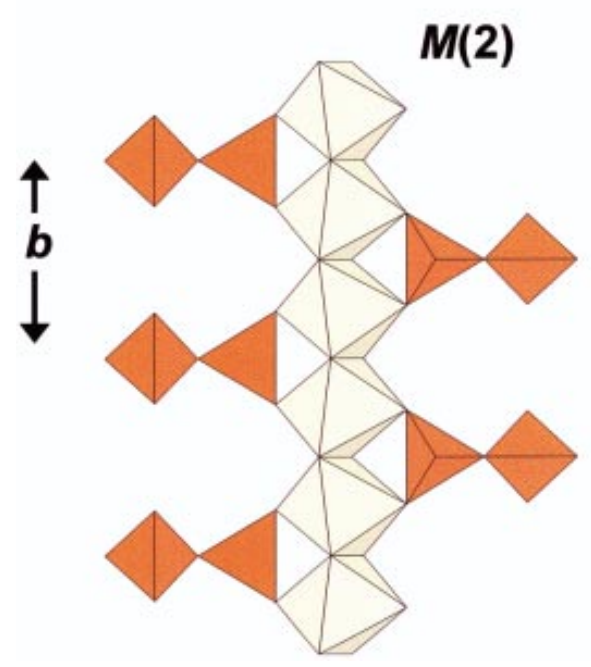

(b)

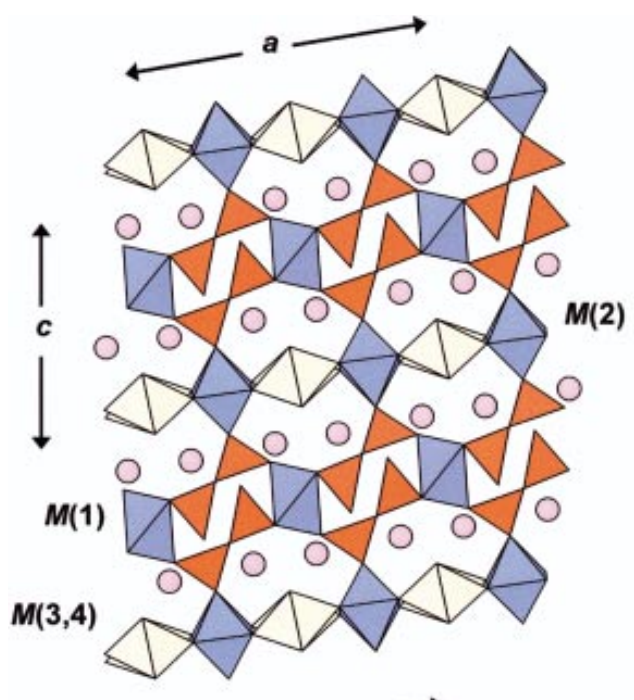

(a)

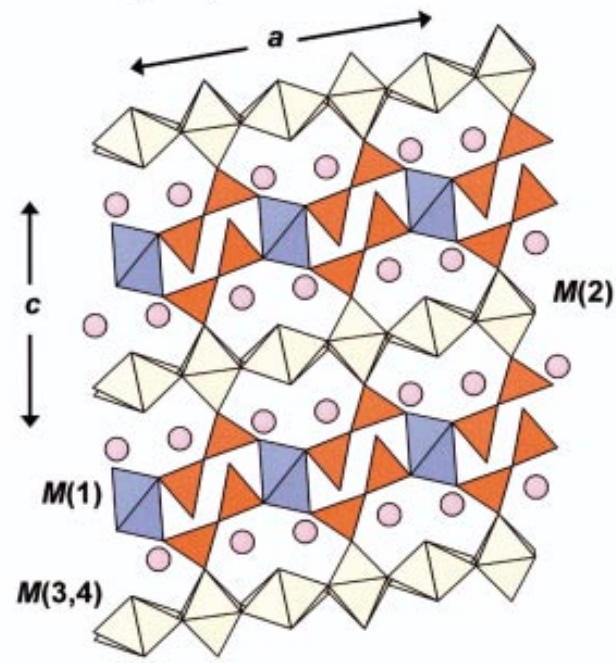

(b)

FIG. 4. The linkage of $\left(\mathrm{SiO}_{4}\right)$ tetrahedra and $M(2)$ octahedra in the crystal structure of chevkinite-(Ce). (a) Assignment $\left(3^{a n}\right)$, see Table 5; (b) assignment $\left(3^{a n}\right)^{*}$. Legend as in Figure 2.

The principal unit of the chevkinite-(Ce) structure is a layer of octahedra parallel to (001) (Figs. 2a, b). This layer consists of two distinct rutile-like chains of octahedra in which each octahedron shares two trans edges with adjacent octahedra; the first chain involves $M(2)$ octahedra, and the second chain involves $M(3)$ and $M(4)$ octahedra. Chains of each type alternate within the layer, and are connected through common vertices. On the basis of the latest data for the chevkinite-group minerals (Macdonald et al. 2002), it is probable that strontiochevkinite and rengeite, as well as perrierite(Ce) (neglecting the fact that perrierite-(Ce) has an $M(3)$

site with a multiplicity of 4; Gottardi 1960), have the same type of layer in their structure (Fig. 2b).

The two site-assignments described above (Table 5) result in two different layers of octahedra with regard to their arrangements of $\left(\mathrm{TiO}_{6}\right)$ octahedra. Figure 2a shows the layer of octahedra corresponding to assignment (3). $\mathrm{Ti}$ is dominant at the $M\left(3^{\mathrm{an}}\right)$ and $M(4)$ sites, and $\mathrm{Fe}^{3+}$ is dominant at the $M(2)$ site. Ideally, the layer consists of regularly alternating $\left[\mathrm{TiO}_{4}\right]^{4-}$ and $\left[\mathrm{Fe}^{3+} \mathrm{O}_{4}\right]^{5-}$ chains. Figure 3 a shows the layer of octahedra corresponding to assignment $\left(3^{\text {an }}\right)^{*}$ (Table 5). Ti is dominant at the $M(2-4)$ sites, producing a layer of corner- and edge- 
sharing $\left(\mathrm{TiO}_{6}\right)$ octahedra. On the other hand, polyakovite-(Ce) has a different arrangement of $\left(\mathrm{TiO}_{6}\right)$ octahedra: $\mathrm{Ti}^{4+}$ and $\left(\mathrm{Cr}^{3+}, \mathrm{Fe}^{3+}\right)$ occur at the octahedrally coordinated M(2-4) sites (Popov et al. 2001) (Fig. 2c).

Chevkinite-(Ce) [plus strontiochevkinite and polyakovite-(Ce)] and perrierite-( $\mathrm{Ce})$ [plus rengeite and matsubaraite] are structural dimorphs. They differ in the linkage of $\left(\mathrm{SiO}_{4}\right)$ tetrahedra and $M(2)$ octahedra (Figs. $3 \mathrm{a}, \mathrm{b})$. Figure $3 \mathrm{a}$ also applies to polyakovite-(Ce): $M(2)$ octahedra are Ti-dominant, as in perrierite-(Ce). Assignments $\left(3^{\text {an }}\right)$ and $\left(3^{\text {an }}\right)^{*}$ suggest that, in the chevkinite(Ce) structure, $\left(\mathrm{SiO}_{4}\right)$ tetrahedra might be linked either to a chain of $\mathrm{Fe}^{3+}$-dominant octahedra (Fig. 4a) or to a chain of Ti-dominant octahedra (Fig. 4b).

Intercalated between these layers are heteropolyhedral chains of $\left[\mathrm{Si}_{2} \mathrm{O}_{7}\right]$ groups and $M(1)$ octahedra (Figs. 5a, b) that extend in the $a$ direction. Two outer vertices of one tetrahedron of the $\left[\mathrm{Si}_{2} \mathrm{O}_{7}\right]$ group link to the apical vertices of $M(2)$ octahedra to form a fairly open heteropolyhedral framework. Regular arrangement of $M(2)$ and $M(3,4)$ octahedra within the layer results in relatively large cages that contain the $A(1)$ and $A(2)$ sites $(\mathrm{CN}=[8]$ and [10], respectively) (Figs. 5a, b). Structure models presented in Figures $5 \mathrm{a}, \mathrm{b}$ differ in the degree of polymerization of $\left(\mathrm{TiO}_{6}\right)$ octahedra. There are rutile-like $\left(\mathrm{TiO}_{6}\right)$ chains in the structure shown in Figure $5 \mathrm{a}$, and there is a sheet of $\left(\mathrm{TiO}_{6}\right)$ octahedra in the structure shown in Figure 5b. Polymerization of $\left(\mathrm{TiO}_{6}\right)$ octahedra is a significant feature of Ti-silicate minerals; we consider this issue elsewhere (Sokolova \& Hawthorne 2004).

\section{ACKNOWLEDGEMENTS}

We thank Andrew Locock and Andy MacDonald for their comments on this paper. FCH was supported by a Canada Research Chair in Crystallography and Mineralogy, by Discovery, Major Facilities Access, and Research Tools and Instruments Grants from the Natural Sciences and Engineering Research Council of Canada, and by Innovation Grants from the Canadian Foundation for Innovation.

\section{REFERENCES}

AINES, R.D. \& Rossman, G.R. (1986): Relationships between radiation damage and trace water in zircon, quartz, and topaz. Am. Mineral. 71, 1186-1193.

Bonatti, S. \& GotTaRdi, G. (1950): Perrierite, nuovo minerale ritrovato nella sabbia di nettuno (Roma). Rend. Acad. Naz. Lincei, Classe sci. fis., mat. e nat., Ser. 8-9, N6, 361-368.

Brown, I.D. (1981): The bond-valence method: an empirical approach to chemical structure and bonding. In Structure and Bonding in Crystals II (M. O'Keeffe \& A. Navrotsky, eds.). Academic Press, New York, N.Y. (1-30).
Calvo, C. \& FagGiani, R. (1974): A re-investigation of the crystal structures of chevkinite and perrierite. Am. Mineral. 59, 1277-1285.

DraKe, M.J. \& Weill, D.F. (1972): New rare earth element standards for electron microprobe analysis. Chem. Geol. 10, 179-181.

GotTARDI, G. (1960): The crystal structure of perrierite. Am. Mineral. 45, 1-14.

HAGGerty, S.E. \& Mariano, A.N. (1983): Strontian-loparite and strontio-chevkinite: two new minerals in rheomorphic fenites from the Parana Basin carbonatites, South America. Contrib. Mineral. Petrol. 84, 365-381.

HAwTHORNE, F.C. \& GROAT, L.A. (1985): The crystal structure of wroewolfeite, a mineral with $\left[\mathrm{Cu}_{4}(\mathrm{OH})_{6}\left(\mathrm{SO}_{4}\right)\right.$ $\left(\mathrm{H}_{2} \mathrm{O}\right)$ ] sheets. Am. Mineral. 70, 1050-1055.

Raudsepp, M., Ball, N.A., Kimata, M., SpiKe, F.D., Gaba, R., Halden, N.M., Lumpkin, G.R., Ewing, R.C., Greegor, R.B., Lytle, F.W., Ercit, T.S., Rossman, G.R., Wicks, F.J., RAMIK, R.A. SHERRIFF, B.L., Fleet, M.E. \& McCammon, C. (1991): Alpha-decay damage in natural titanites. Am. Mineral. 76, 370-396.

INTERNATIONAL TABLES FOR X-RAY CRYSTALLOGRAPHy, Vol. C (1992): Kluwer, Dordrecht, The Netherlands.

KARTASHOV, P.M. (1994): Zr- and Nb-bearing varieties of chevkinite-(Ce) and their alteration products, first occurrence in Mongolia. Ninth IAGOD Symp. (Beijing) 2, 696697 (abstr.).

Kovalenko, V.I., Tsaryeva, G.M., Goreglyad, A.V., Yarmolyuk, V.V., Troitsky, V.A., Hervig, R.L. \& FARMER, G.L. (1995): The peralkaline granite-related Khaldzan-Buregtey rare-metal (Zr, Nb, REE) deposit, Western Mongolia. Econ. Geol. 90, 530-547.

Lian, J., Wang, L., Chen, J., Sun, K., Ewing, R.C., MatT FARMER, J. \& BOATNER, L.A. (2003): The order-disorder transition in ion-irradiated pyrochlore. Acta Materialia 51, 1493-1502.

Macdonald, R., Marshall, A.S., Dawson, J.B., Hinton, R.W. \& HILL, P.G. (2002): Chevkinite-group minerals fom salic volcanic rocks of the East African Rift. Mineral. Mag. 66, 287-299.

Miyajima, M., Matsubara, S., Miyawaki, R., Yokoyama, K. \& HIROKAWA, K. (2001): Rengeite, $\mathrm{Sr}_{4} \mathrm{ZrTi}_{4} \mathrm{Si}_{4} \mathrm{O}_{22}$, a new mineral, the $\mathrm{Sr}-\mathrm{Zr}$ analogue of perrierite from the Itoigawa-Ohmi district, Niigata Prefecture, central Japan. Mineral. Mag. 65, 111-120.

MiYawaKi, R. \& ITo, K. (2002): Matsubaraite, $\mathrm{Sr}_{4} \mathrm{Ti}_{5}\left(\mathrm{Si}_{2} \mathrm{O}_{7}\right)_{2} \mathrm{O}_{8}$, a new mineral, the $\mathrm{Sr}-\mathrm{Ti}$ analogue of perrierite in jadeitite from the Itoigawa-Ohmi district, Niigata Prefecture, Japan. Eur. J. Mineral. 14, 1119-1128. 
NiCKEL, E.H. \& MANDARINO, J.A. (1987): Procedures involving the IMA Commission on New Minerals and Mineral Names and guidelines on mineral nomenclature. Can. Mineral. 25, 353-377.

Parodi, G.C., Della Ventura, G., Mottana, A. \& Raudsepp, M. (1994): Zr-rich non-metamict perrierite-(Ce) from holocrystalline ejecta in the Sabatini volcanic complex (Latium, Italy). Mineral. Mag. 58, 607-613.

Peng, C.C. \& Bun, V.R. (1964): The crystal structure of chevkinite. Scientia Sinica XIII, 1539-1545 (in Russ.).

Popov, V.A., Pautov, L.A., Sokolova, E., Hawthorne, F.C. McCammon, C. \& Bazhenova, L.F. (2001): Polyakovite(Ce), $(\mathrm{REE}, \mathrm{Ca})_{4}\left(\mathrm{Mg}, \mathrm{Fe}^{2+}\right)\left(\mathrm{Cr}^{3+}, \mathrm{Fe}^{3+}\right)_{2}(\mathrm{Ti}, \mathrm{Nb})_{2} \mathrm{Si}_{4} \mathrm{O}_{22}, \mathrm{a}$ new metamict mineral species from the Ilmen Mountains, southern Urals, Russia: mineral description and crystal chemistry. Can. Mineral. 39, 1095-1104.

SHANNON, R.D. (1976): Revised effective ionic radii and systematic studies of interatomic distances in halides and chalcogenides. Acta Crystallogr. A32, 751-767.
SHELDRICK, G.M. (1997): SHELXL97, Program for the solution and refinement of crystal structures. University of Göttingen, Göttingen, Germany.

(1998): SADABS User Guide. University of Göttingen, Göttingen, Germany.

Sokolova, E. \& Hawthorne, F.C. (2004): The crystal chemistry of silicate minerals with chains of $\left(\mathrm{TiO}_{6}\right)$ octahedra. Can. Mineral. 42, 807-824.

Yang, Zhuming, Fleck, M., Smith, M., Tao, Keje, Song, RENKUI \& ZHANG, PEISHAN (2002): The crystal structure of natural Fe-rich chevkinite-(Ce). Eur. J. Mineral. 14, 969975.

Received July 20, 2002, revised manuscript accepted June 30 2004 